\title{
Material waste in the construction industry: a review of the legislative and supply chain issues
}

\author{
Chika Udeaja, Damilola Ekundayo, Lei Zhou, and Srinath Perera \\ Quantity Surveying Group, Faculty of Engineering and Environment, \\ Northumbria University, Newcastle upon Tyne, NE1 8ST, \\ United Kingdom \\ Email: chika.udeaja@northumbria.ac.uk; damilola.ekundayo@northumbria.ac.uk; \\ lei.zhou@northumbria.ac.uk; and srinath.perera@northumbria.ac.uk
}

\subsection{Introduction}

There is now clear scientific proof which indicates that emissions of greenhouse gases, particularly $\mathrm{CO}_{2}$, are the main cause of climate change (DCLG, 2006). Over the last few years, some interesting research on this subject has begun to emerge (Barret et al., 1999; Zsidisin and Siferd, 2001; Shayoh et al., 2002; Horvath, 2004; Ding, 2005; Fergusson and Langford, 2006; Kibert, 2007; Ball et al., 2009). In construction, contemporary arguments suggest that the built environment is responsible for half of all $\mathrm{CO}_{2}$ emissions, half of water consumption, one third of landfill waste and one quarter of raw materials used in the UK (BERR, 2008). In recent years, one of the key drivers in promoting environmental issues within construction has been sustainable development and, in particular, material usage and waste (Chaharbaghi and Willis, 1999; Khalfan, 2002; Gupta and Chandiwala, 2007; Ferguson et al., 1995; Faniran and Caban, 1998; Yahya and Boussabaine, 2006; Srivastava, 2007).

Material waste is becoming a serious environmental problem in many large cities around the world. In the UK, the construction industry generates lots of waste which has a significant impact on the environment (i.e. demand for landfill and the depletion of natural resources) (Ferguson et al, 1995). Each year, poor design and site management leads to approx $13 \%$ of all solid materials delivered to sites, some 10 million tonnes, going unused. This makes the construction industry the largest generator of controlled waste going to landfill (NCE, 2007; WRAP, 2007). Waste production on construction sites is often down to inadequate storage and protection, poor or multiple handling, poor site control, over-ordering of materials, bad stock control, lack of training, and damage to materials during delivery (DETR, 2000; WRAP, 2007). Increased pressure on landfill sites, accompanied by rising prices, strict controls and taxation, and a growing understanding of the environmental issues surrounding waste disposal has made the minimisation of construction waste an absolute necessity (Ferguson et al, 1995). Reviews by Egan (Egan Report, 1998, 2002) suggested that $30 \%$ of construction is rework and at least $10 \%$ of materials are wasted. But he believed that there is plenty of scope for improving efficiency and quality simply by taking waste out of construction. The amount of waste construction generates continues to be a major problem for the industry and in many countries.

What is clear is that the UK construction industry aims to contribute to waste reduction or elimination by adopting new policies and practices, which have a more positive impact on economic, social and environment systems. Improvements are sought in all stages of the construction process, such as land use, replenishment of natural resources, transport networks, construction processes, embodied energy of building whilst in use, social interaction and economic benefits for the whole supply chain. The work outlined in this book chapter attempts to review material waste in construction industry focusing on the legislative and supply chain issues. To achieve this, a review was undertaken to introduce the construction activities in relation to the environment impact. It discusses the sustainability agenda, but paying particular attention to the 
sustainable construction principles and characteristics. The second part of the review identifies the origin and concept of waste in construction and underlines the strategies for waste minimisation as reported by researchers in this area. The third part, reviews the legislative and supply chain issues that affect waste management in construction. In order to gain a better understanding of the construction waste minimisation strategies, the review examined a number of industrial/research projects using case study examples in construction. The final part discusses the contribution of the book chapter and makes recommendation that a holistic approach is required for construction waste minimisation and management.

\subsection{Construction activity and the environment}

This section starts with an overview of sustainable development (SD). The construction industry is critical to meeting the sustainability agenda due to the enormous amount of materials it consumes (both renewable and non-renewable) the vast amount of waste it produces/generates and the impact of its products on the natural and man-made environments. Hence, this section further explores the concept of sustainable construction and concludes with an overview of the life cycle phases of building materials and their associated environmental impacts.

\subsection{Overview of sustainable development}

In 1987, the United Nations Brundtland Commission offered what may be the definitive explanation of the term sustainability or sustainable development (Mills, 2010). According to the report of the World Commission on Environment and Development, Our common future, it is the development that meets the needs of the present without compromising the ability of future generations to meet their own needs (WCED \& Brundtland, 1987). Indeed, the Brundtland report remains one of the most cited works in the field. However, several other global events have since taken place with debate on topical issues including sustainability. Amongst these are the Earth Summits in Rio de Janeiro 1992, New York 1997 and Johannesburg 2002, the Conference of the Parties to UN Framework Convention on Climate Change (UNFCCC) in Kyoto, 1997, and possibly the awarding of the Nobel Peace Prize to Al Gore and the Intergovernmental Panel on Climate Change (IPCC).

A common feature of the above notable events has been the ability to trigger and/or alter the debate around sustainable development and to maintain the importance of sustainability relative to when the word was first coined. In effect, on a global level, sustainable development continues to grow in awareness. This seems to be of an incremental nature, possibly due to these distinctly associated events. The assertion that only very few truly global events can be identified that triggered a substantial amount of media coverage globally, tells a lot about the supreme importance, sustained level of interest and growing concerns associated with the subject matter of sustainability.

In recent years, after the publication of the Brundtland Report, the term sustainability has been widely adopted by both the public and private sectors. According to Barkemeyer et al. (2009), the coverage of sustainable development seems to have reached the mainstream public arena, in the local, national and on a global level. These terms are now in common use in scientific papers, monographs, textbooks, annual report of companies, government policy usage, and the media (Glavic \& Lukman, 2007). In fact, it is so overused that it has given birth to new lexicons, with words such as green supply chain management, green procurement and green buildings becoming commonplace and gaining currency to describe the many attempts to co-opt the issue (Mills, 2010).

The term sustainability or sustainable development has been, and it is still being, subject to a range of interpretations given its broad meaning. It is therefore paramount to look at the fundamental concept of the term. The different definitions of SD imply that application of the term depends on their designation and recognition in different disciplines such as in construction. However, the domain concept remains the same and must not be misplaced- not least because it helps to avoid 
much confusion in their usage but it also helps to achieve better and easier understanding. In view of this, Edum-Fotwe \& Price (2009) suggested that SD should be supported by a common, unambiguous and fundamental concept.

Earlier, WCED \& Brundtland (1987) stated categorically that the interventions needed to achieve sustainable development must be conceived and executed by processes that integrate environmental, social and economic considerations which are the fundamental principles. In a recent study, having analysed fifty-one definitions from diverse sources, Glavic \& Lukman (2007) concluded that the environmental/ecological, economic, and societal principles are connected to all dimensions of sustainable development. The authors further noted that all the definitions examined have interconnections between environmental protection, economic performance and societal welfare. In conclusion, numerous definitions have emerged over the years and various applications of sustainable development are attainable in this present era, but in principle, they remain similar to the one from 1987 (Glavic \& Lukman, 2007).

\subsection{Sustainable construction}

Awareness and significance of sustainable development have been growing around the world for the last few decades (Khalfan, 2006). Sustainable construction is now considered as a way for the construction industry to contribute to this global agenda (Ding, 2005; Majdalani, Ajam, \& Mezher, 2006). In the UK, the construction industry remains one of the most critical sectors for the adoption of sustainable development principles. This is due to its size, accounts for $8 \%$ of GDP, the enormous amount of materials and resources it consumes and the vast amount of waste it generates (BERR, 2008; GCCP, 2000; Raynsford, 1999; Spence \& Mulligan, 1995). As a result, the construction industry outputs have a significant impact on the built and natural environments in particular, and the society at large (BERR, 2008; GCCP, 2000; Raynsford, 1999; Spence \& Mulligan, 1995). For example, the industry is one of the largest contributors to the greenhouse gases causing climate change; one of the greatest global environmental threats facing our civilisation today (Hammond \& Jones, 2008a; Sturgis \& Roberts, 2010). Greenhouse gases are mainly composed of carbon (Ekundayo et al., 2011) and in the UK, the carbon related to buildings amount to around $47 \%$ of the total greenhouse gases causing climate change (BIS, 2010).

Right across the world, sustainable construction is gaining awareness and in the UK, this continues to be driven by the industry, the UK Government, and EU regulations e.g. Energy Performance of Buildings Directive 2002 (BIS, 2010). In recent times in the UK, developing more sustainable buildings continues to dominate the government agenda and this is being pursued vehemently through different strategies (DECC et al., 2008). Also, the private sector has begun to incorporate sustainability into their services and products not only because it is the right thing to do but because of the inevitable government legislations and policies coupled with corporate social responsibility agenda (BIS, 2010). There have been several industry attempts to encourage sustainability in general and sustainable construction in particular. Such include the development of various sustainability assessment techniques such as the Codes for Sustainable Homes (CSH), Building Research Establishment Environmental Assessment Method (BREEAM) and the Green Guide amongst others. Also the terms such as green supply chain management, green building, zero carbon homes, and carbon counting have been bandied around recently and they all are a growing recognition of the need for sustainable development and construction.

More formal attempt by the government include, for example, the Climate Change Act 2008, which now makes it a legal obligation in the UK to reduce carbon to achieve environmental sustainability, and different targets set to enhance this commitment. Compared with the 1990 baseline, 26\% reduction is expected by 2020 and no less than $80 \%$ by 2050 according to the recent government reports (BIS, 2010; DECC et al., 2008). Furthermore, a range of environmental tax, levy, incentives and market mechanisms have been put in place to support this obligatory commitment (Monahan \& 
Powell, 2011; Pellegrini-Masini, Bowles, Peacock, Ahadzi, \& Banfill, 2010). The UK government and industry have taken considerable measures to promote building sustainability by developing legislation such as Part L of the Building Regulations, and formalised methods of managing carbon due to operational energy usage in new buildings. Operational energy usage and carbon emissions of buildings can now be quantified by various standard assessment methods such as Energy Performance Certificates (EPCs) and Display Energy Certificate (DECs) (BIS, 2010; Sturgis \& Roberts, 2010).

In view of the above, Myers (2008) stressed the importance of sustainable development in the construction industry. It is clear why the construction industry must respond accordingly and focus its attention on developing sustainable buildings which are economically viable, socially acceptable and environmentally friendly. In particular, there continues to be greater emphasis on sustainable buildings that have less impact on the environment (RICS, 2012). Coupled with this is the increasing need for the judicious use of the irreplaceable, dwindling natural resources (Emmanuel \& Baker, 2012). To this end, building materials capable of being reused and/or recycled at the end of their useful life are becoming popular and being encouraged in sustainable projects. For example, the Waste and Resources Action Programme (WRAP) is a typical example of an initiative set up to encourage recycling and the use of recycled products in new buildings (Salisbury, 2006). The next section therefore examines the building materials' life cycle phases and their associated environmental impacts.

\subsection{Building materials' life cycle phases}

The construction industry utilises different materials and by products, many of which have considerable environmental impacts. Some of these materials can be recycled and reused while several others are non-renewable. There is therefore a growing need to focus on the judicious use of the dwindling natural resources from which these materials are being produced. Perhaps, more importantly is the need to minimise waste in the building materials life cycle phases in order to reduce carbon, which is fast becoming a significant measure of environmental impacts (Hammond \& Jones, 2008a). This section therefore briefly identifies the different phases of a building material's life cycle and the associated carbon emissions. These are referred to as system boundaries. The most popular system boundaries as identified by various proponents in this field (Anderson, Shiers, \& Steele, 2009; Ekundayo et al., 2012; Franklin and Andrews, 2010; Hammond \& Jones, 2008b; RICS, 2012) include:

a. Cradle-to-Gate: all carbon emitted from material extraction to manufacture and until the final product leaves the last factory gate.

b. Cradle-to-Site: i.e. cradle-to-gate carbon emissions plus carbon emissions as a result of material transportation to site.

c. Cradle-to-End of construction: i.e. cradle-to-site carbon emissions plus carbon emissions due to site assembly and construction activities.

d. Cradle-to-Grave: all carbon emitted in cradle-to end of construction plus carbon emissions as a result of building maintenance and disposal at the end of life.

e. Cradle-to-Cradle: this system boundary applies only to re-useable building materials i.e. cradleto-grave plus carbon emissions due to recycling.

In brief, carbon embedded in materials, commonly referred to as embodied carbon, is due to the energy used in their extraction, manufacture and transportation etc. (Emmanuel \& Baker, 2012; Hammond \& Jones, 2008a). Consequently, any waste minimisation strategy deployed at any of the building materials' life cycle phases identified above will help to reduce environmental impact a great deal. 


\subsection{Concept of Waste}

Having discussed, albeit briefly, the sustainable development issues, the purpose of this section is to discuss the concept of material waste and its related topics such as waste minimisation and management strategies and current practices in construction.

\subsection{Material Waste}

One of the fundamental themes of sustainable construction is material usage and wastage (Ferguson et al., 1995; Faniran and Caban, 1998; Yahya and Boussabaine, 2006; Srivastava, 2007). Material waste is becoming a serious environmental problem in many large cities in the world. Report by Egan (Egan Report, 1998, 2002) suggested that 30\% of construction is rework and at least $10 \%$ of materials are waste. But he believed that there is plenty of scope for improving efficiency and quality simply by taking waste out of construction. The amount of waste construction generates continues to be a major problem for the industry and in many countries. Previous studies suggest that construction is a major contributor to the generation of waste all over the world (Craven et al., 1994; Kartam et al., 2004; Begum et al., 2006; Tam et al., 2007; Jaillon et al., 2009). However, the figures appear not to be consistent from country to country, but what is clear is that the waste in construction is substantial compared to other industries. CRW (2008) used a chart as shown in Figure 1 to show how the relative impact of construction sector waste, when set against overall waste in England appears to be the greatest. It also argued that construction-related waste are evident in other sectors such as 'mining \& quarrying' (primary aggregates/raw material production) and 'industrial' (construction product manufacture) (see Figure 1).

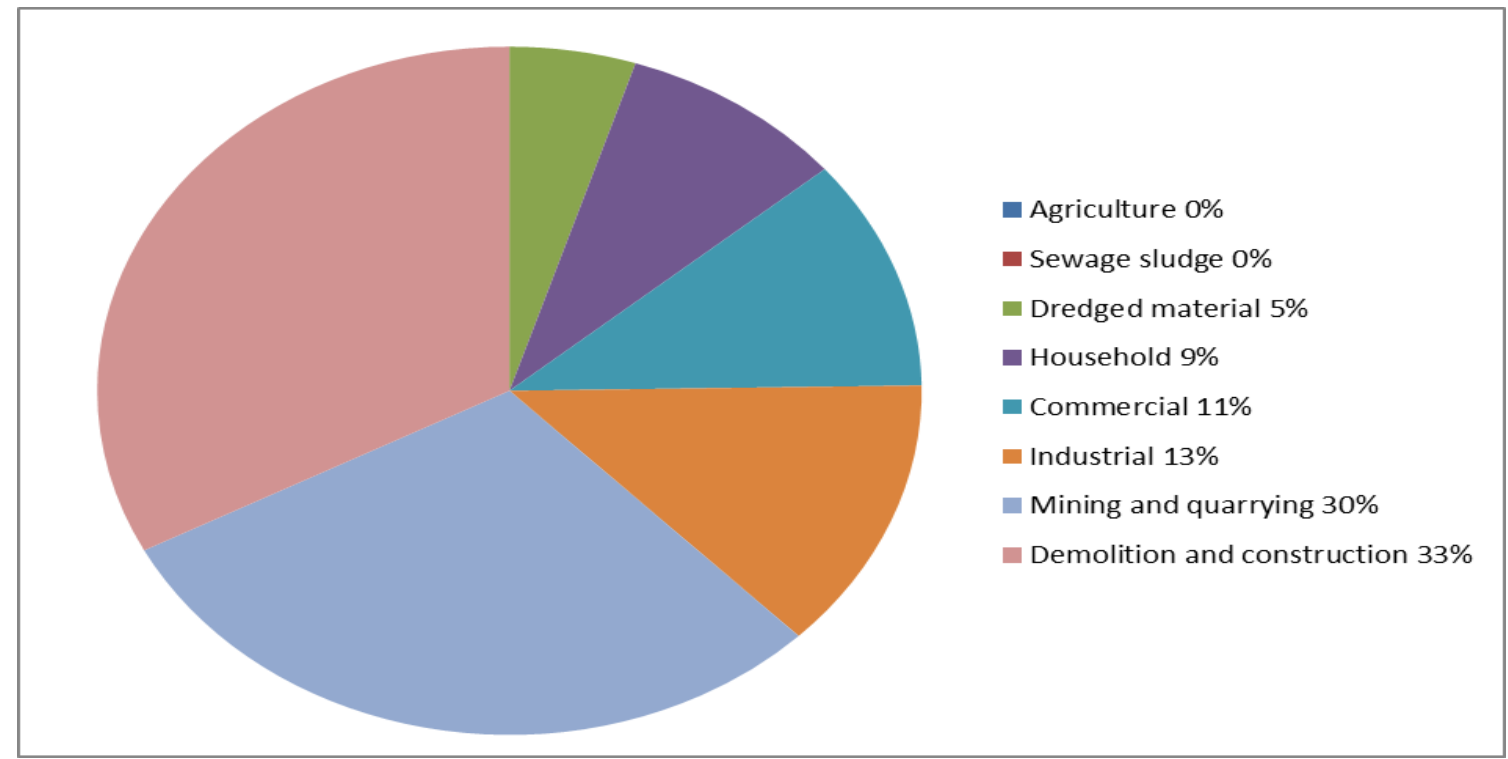

Figure 1: Composition of waste production in England (adapted from CRW, 2008).

Over 2 billion tonnes of waste are generated in the European Union every year, approximately half of which is produced by the construction industry (Ferguson et al, 1995). Globally, findings show that approximately $40 \%$ of waste generated originates from the construction industry (Nitivattananon and Borongan, 2007). BERR (2007) highlights that in the UK alone construction produces more than 100 million tonnes of waste a year, representing more than $50 \%$ of the total waste production of the country. Of this waste, more than 60 million tonnes goes straight to landfill, three times more than all the domestic waste produced by the UK's twenty one million homes. This makes the construction industry the largest generator of controlled waste going to landfill (NCE, 2007).

\subsection{Material waste in Construction}


Waste in the construction industry has been the subject of several research projects around the world in recent years (Teo and Loosemore, 2001; Formoso et al., 2002; Kartam et al., 2004; Venters et al., 2005; Tam et al., 2007; Jaillon et al., 2009). Some of these researches have focused on the environmental damage that results from the generation of material waste (Formoso et al., 2002) and others have focused on the industry's discourse addressing efficiency issues such as adaptation of present practice (i.e. the need to design \& construct building in different ways, for ease of demolition as well as ease of construction) and the creation and application of new knowledge (i.e. the adoption of new sustainable ideas and concepts) (Venters et al., 2005). When considering construction material waste, it is important to define what is meant by the term "construction material waste". Skoyles (1978) cited in McDonald and Smithers (1998) defined material waste as the difference between materials ordered and those placed for fixing on construction projects. More recent proponents such as Formoso et al (1999), Ekanayake and Ofori (2004) and Tam et al (2007) argue that material waste should be defined as any negative activities that generates direct and in-direct cost but do not add any value to the project. In a related issue, contemporary research into the problems and solutions of waste in construction projects suggested that waste can occur at any stage of the construction process from conceptualisation, through to the design, construction and demolition of the construction infrastructure (Bossink and Brouwers, 1996; Teo and Loosemore, 2001; Danity and Brooke, 2004; Osmani et al., 2008). In a sense, this resonates with Kwan et al (2001), who argued that construction waste can be divided into two main categories, namely, waste generated due to design and specification, and waste generated by construction activities. The above studies have shown that the most significant sources of construction waste are generated during the construction phase (usually stemming from Poor storage, protection, and site control; Poor or multiple handling; Poor quality material; Inaccurate or over ordering of materials or leftover; Inefficient use of materials; Bad stock control; Lack of training; Damage to materials during deliveries; Damage generated by poor co-ordination with other trades and Theft and vandalism). However, Formoso et al (1999) in classifying waste, argued that there can be unavoidable waste (or natural waste), in which the investment necessary to its reduction is higher than the economy produced; and avoidable waste, where the cost of waste is significantly higher than the cost to prevent it. In a more recent discussion, Jaillon et al (2009) identified that construction waste can be categorised into two major forms, namely, inert materials (i.e. soft and hard inert materials) and non-inert waste.

\subsection{Waste Minimisation and management Strategies}

Waste minimisation involves any process, method or activity, which reduces, negates or eradicates waste at its source, or allows recycling to enable re-use (Crittenden and Kolaczkowski, 1995). This also takes into consideration materials emitted into water, air and land, including energy consumption. Osmani (2012) states the accepted definition of construction waste minimisation is "the reduction of waste at source, (i.e. designing out waste) by understanding its root causes and re-engineering current processes and practices to alleviate its generation". In this section, two distinct procedures in addressing construction waste will be considered. The first considers the minimisation of waste generated through source reduction techniques during the design and procurement phases of a project (McDonald and Smithers, 1998, Wrap, 2007; Osmani et al., 2008). The second as discussed by Chen et al (1994), Yuan and Shen (2008) and Velazquez et al (2011) adopt an effective system for managing the unavoidable waste produced. In managing the unavoidable waste, Teo and Loosemore (2001) and Tam et al (2007) identified that three hierarchical methods have been established, namely, reuse, recycling and disposal. Teo and Loosemore (2001) further argued that the balance between the three will depend upon the nature of the waste, legislative requirements for specific materials and the cost effectiveness of each method. In order to create a practical waste minimisation and management strategy, a comprehensive understanding of the causes of construction waste is needed. This knowledge is an essential part of the strategy as it allows effective methods for dealing with these wastes at their source to be established. 
Past research into the causes of waste in construction projects indicates that waste can arise at any stage of the construction process from inception, right through the design, construction and operation of the built facility (Spivey, 1974; Craven et al. 1994; Gavilan and Bernold, 1994; Faniran and Caban, 1998). Experienced practitioners in the waste and environmental pollution field recommend that minimisation of waste at source should be given the highest priority when developing strategies for waste minimisation (Crittenden and Kolaczkowski, 1995). This is because, it makes more sense to avoid or minimise the generation of waste than to develop extensive schemes for treating waste (Faniran and Caban, 1998). Waste is still perceived as a low project priority, and there is an absence of appropriate resources and incentives to support it (Teo and Loosemore, 2001). However, it is likely that attitudes will vary across different organisations according to their culture and waste management policies and across the various occupational groups in the construction industry. As more stringent controls are increasingly being placed on landfill sites, the cost of disposing of construction waste is set to rise steadily thereby, becoming a major cost in construction projects. Furthermore, the release of polluting emissions during the construction production process and the transportation of contaminated waste are potential hazards to the environment. The generation of construction waste also contributes to the depletion of raw materials used in the construction industry (Faniran and Caban, 1998).

\subsection{Previous Research work}

Having introduced the concept of waste minimisation in relation to environmental sustainability, this section will report other related work in this area. The research projects in the area of waste management/minimisation cut across various disciplines and sectors in the construction industry and employs variety of strategies and concepts. Consequently, this section outlines a number of issues that have been applied in construction industry to reduce waste. The discussions are briefly presented in Table 1 below.

\section{Table 1: Previous Research in Waste Minimisation strategies}

\begin{tabular}{|l|l|}
\hline $\begin{array}{l}\text { Research Topics generation and } \\
\text { reduction }\end{array}$ & $\begin{array}{l}\text { Quantification of waste reduction using prefabrication (Jaillon et } \\
\text { al., 2009) and (Tam et al., 2007); } \\
\text { SMARTWaste - software tool that audit, reduce and target waste } \\
\text { on construction site (McGrath, 2001; and } \\
\text { Developing a bar-code system for auditing and assessing } \\
\text { construction waste (Chen et al., 2002). }\end{array}$ \\
\hline $\begin{array}{l}\text { Waste reuse and } \\
\text { recycling }\end{array}$ & $\begin{array}{l}\text { Improvement of on-site waste management practices (Mcdonald } \\
\text { and Smithers, 1998); } \\
\text { Development of a construction and demolition waste recycling } \\
\text { operations (Peng et al., 1997); } \\
\text { Use of BIM to aid construction waste minimisation (Zhen et al., } \\
\text { 2011); and and } \\
\text { Mapping approach for examining waste management on } \\
\text { construction site (Shen et al., 2004). }\end{array}$ \\
\hline $\begin{array}{l}\text { Waste minimisation and } \\
\text { management in general }\end{array}$ & $\begin{array}{l}\text { Eco-costing of construction waste (Yahya and Boussabaine, } \\
\text { 2006); } \\
\text { Adoption of supply chain integration for effective waste } \\
\text { minimisation measures (Danity and Brooke, 2004); } \\
\text { The use of learning by offering the most used and insightful } \\
\text { concepts of sustainability to management waste (Velazquez et } \\
\text { al., 2011); } \\
\text { Implementation of governmental ordinances in controlling } \\
\text { construction waste (Tam et al., 2007); }\end{array}$ \\
\hline
\end{tabular}




\begin{tabular}{|l|l|}
\hline $\begin{array}{l}\text { Greening the supply chain management (Srivastava, 2007), } \\
\text { (Ofori, 2000) and (Beamon, 1999); and } \\
\text { Implementation of theory of waste behaviour that helps } \\
\text { managers improve operatives' attitudes towards waste (Teo and } \\
\text { Loosemore, 2001). }\end{array}$ \\
\hline
\end{tabular}

While the list of previous works in the area of waste minimisation strategies in this section is not exhaustive, it does indicates the wide range of proliferation of research projects that should be considered in determining a more sustainable course of action for the reduction or elimination of waste in construction projects. Achieving good waste minimisation and management on construction projects will help reduce quantities of waste being sent to the landfill and will in effect make significant contribution towards sustainable development in general and environmental sustainability in particular (Wrap, 2007).

\subsection{Perceived challenges facing the Construction Industry}

This section reviews the current legislations and the supply chain challenges and highlights the fact that UK legislations have covered the fundamental requirements within the construction waste. Two cases have been introduced to demonstrate the best practice of waste management on construction site and the carrot-stick effects of legislations and the government's financial incentives. These legislations are existed and now need to be enforced strictly in supply chain management and the construction practice.

\subsection{Legislative Issues}

There are currently a wide variety of UK legislations and policies that have direct or indirect impacts on the construction waste management and the need to recover resources from demolition (CRWP, 2007). These government legislations can be categorised into three areas: 1) environmental protection and sustainable construction regulations; 2) waste management regulations and 3) fiscal policies. They are listed in the table 2 below:

Table 2: List of UK Waste Management Legislations

\begin{tabular}{|c|c|c|}
\hline Category & Legislations & $\begin{array}{l}\text { Year } \\
\text { Published }\end{array}$ \\
\hline \multirow{7}{*}{$\begin{array}{l}\text { Environmental } \\
\text { Protection and } \\
\text { Sustainable } \\
\text { Construction }\end{array}$} & Environmental Protection Act & 1990 \\
\hline & Environmental Protection (Duty of Care) Regulations & 1991 \\
\hline & Clean Neighbourhoods and Environment Act & 2005 \\
\hline & Code for Sustainable Homes & 2006 \\
\hline & Landfill (England \& Wales) Regulations & \\
\hline & Sustainable Construction Strategy & 2008 \\
\hline & Climate Change Act & 2008 \\
\hline \multirow{7}{*}{$\begin{array}{l}\text { Waste } \\
\text { Management } \\
\text { regulations }\end{array}$} & The Waste Management Licensing Regulations & 1994 \\
\hline & Special Waste Regulations & 1996 \\
\hline & $\begin{array}{l}\text { Controlled Waste (Registration of Carriers and Seizure } \\
\text { of Vehicles) (Amendment) Regulations }\end{array}$ & 1998 \\
\hline & $\begin{array}{l}\text { Planning Policy Statement 10: Planning for Sustainable } \\
\text { Waste Management }\end{array}$ & $\begin{array}{l}1999 \\
\text { (revised in } \\
2011 \text { ) }\end{array}$ \\
\hline & The Hazardous Waste (England and Wales) Regulations & 2005 \\
\hline & Site Waste Management Plan (SWMP) & 2008 \\
\hline & ICE demolition Protocol & 2008 \\
\hline \multirow[t]{2}{*}{ Fiscal Policies } & Landfill Tax Regulations & 1996 \\
\hline & Climate Change Levy & 2001 \\
\hline
\end{tabular}




\section{Environmental protection and sustainable construction}

- The Environmental Protection Act 1990 (UK Government, 2012), was one of the earlier forms of waste legislation in the UK, section 33 of the act covers the treatment, storage and disposal of construction waste. The Act requires that, while on site, waste must be stored in such a way as to prevent it from causing damage to the environment or posing a risk to human health.

- Environmental Protection (Duty of Care) Regulations 1991. The aim of Duty of Care is to stop waste producers from simply handing waste over, without considering where it will be going. On a construction site, the waste producer is the person carrying out the work which gives rise to the waste, not the person who issues instructions or establishes contracts which give rise to waste. Where a haulier is brought by the main contractor to remove a sub-contractors waste, the main contractor is acting as a broker and all three parties (haulier, the main contractor and the sub-contractor) are therefore subject to the duty. Wherever waste is being stored, it must not be allowed to escape. This requests that all containers/skips must be safe and secure, and they should also be labelled accurately and accordingly.

- The Clean Neighbourhoods and Environment Act 2005 (UK government, 2013) contains a variety of environmental measures, including changes to the system of recycling credits. This act provides local authorities with more effective powers to solve certain environmental issues, such as how to deal with abandoned vehicles, graffiti, waste and noise etc.

- The Code for Sustainable Homes (CLG, 2006) will establish new voluntary standards for resource efficiency on issues such as energy, water, waste and materials, which could collectively deliver significant carbon savings. The Code encourages builders to minimise resource use from the start, and will be updated as technology develops. At the moment, this is only mandatory for government housing, and it is still voluntary for private housing. However, the Code is currently being developed to apply to all new homes in England.

\section{Waste management regulations}

- The Waste Management Licensing Regulations (1994 and amendments) is the legislative document setting out the procedure for obtaining a licence. It is applied to persons or businesses that dealing with waste on site (i.e. collection, storage, treatment, recycle or disposal). In 2008, the Waste Management Licensing Regulations were replaced for England and Wales by the Environmental Permitting Regulations 2007.

- The Hazardous Waste (England and Wales) Regulations 2005. Regulation 19 within the legislation prohibits the mixing of hazardous waste with other classes of hazardous waste, and with non-hazardous waste. Producers of hazardous waste are obliged to notify their premises to the Environment Agency every 12 months, and a fee is payable.

- Site waste management plan (SWMP) (UK government, 2008) were originally employed under a voluntary code of practice in 2004, however, these are now compulsory in England as of $6^{\text {th }}$ April 2008 for all construction projects worth over $£ 300,000$. Although SWMP are not legally required in Scotland, under Scottish Planning Policy the Scottish Government and SEPA both recommend SWMPs as good practice.

- This ICE protocol (ICE, 2008) has been developed to provide an overarching framework which enables the waste hierarchy to inform approaches for managing buildings and structures at the end of their lives. The demolition protocol was firstly launched in 2003 and it has been adopted 
and implemented across a range of public and private sector projects. The 2008 edition put greater emphasis on how the aims of the waste hierarchy can be achieved. It describes the overarching implementation approaches for Materials Resource Efficiency (MRE) associated with demolition and construction activities, with a decision-making framework which emphasises the need to reuse, then recycle, with landfill as a last resort.

\section{Financial Incentive/Tax Policies}

- The Landfill Tax (1996) is influencing waste management practices by encouraging greater diversion of waste from landfill. Costs of disposing of construction and demolition waste to landfill can be minimised through more efficient construction and innovative re-use and recycling of materials. The landfill tax, which is levied on the disposal of waste to landfill sites throughout the UK in 1996. It aims to encourage waste producers to produce less waste, recover more value from waste (for example through recycling or composting), and to use more environmentally friendly methods of waste disposal. There are three disposal rates, $£ 2$ per tonne for inert waste, $£ 18$ for non-hazardous and $£ 21$ per tonne for hazardous wastes. These rates change regularly and are expected to rise by $£ 3 /$ year until hazardous waste reaches $£ 35$ per tonne in 2010 (Zhou, 2009).

- The Aggregate Levy was introduced in April 2002. It reflects the environmental costs of aggregate quarrying and aims to reduce demand for primary aggregates by increasing their cost, which in turn makes the use of recycled and secondary materials such as mineral waste and recycled construction and demolition waste. By increasing the tax levies, contractors need to source new suppliers for secondary aggregates or they could recycle construction waste from the demolition site (Zhou, 2009).

\subsection{Supply Chain Issues}

There is a consensus in the literature that a significant portion of waste is caused by construction activity (Bossink and Brouwers, 1996; Faniran and Caban, 1998; Osmani et al., 2008). Ofori (2000) identified that the construction supply chains are usually fragmented, and often involves several parties with different objectives. He further argued that none of these parties normally assumes direct responsibility for minimising or managing waste. Previous researches on waste in construction reveal that it can arise at either the upper or lower stream of the supply chain or network (Ofori, 2000; Hicks et al., 2004; Srivastava, 2007; Walker et al., 2008). These studies have also shown that the most significant challenging issues within the supply chain to waste minimisation come from the nature of the organizations (i.e. contractors, subcontractors, suppliers, etc.), the people that compose the organization and the nature of clients (i.e. one-off customers, government, private etc.). These challenges have been classified under external and internal supply chain issues and they are discussed below:

- Lack of integration in the industry - The construction industry has been characterised by fragmentation and lack of integration. It was found that significant barriers exist to waste management within the construction sector, which stem from lack of integration within a project team in a construction project. Improving the collaboration between the parties within the construction industry will enhance productivity whilst maximising efficiency and effectiveness.

- The regulation at present are considered as a soft touch - Under the current regulation, the design team have been able to attain excellence by paying lip service to sustainable design. This goes to prove that the current regulations are not tough enough to implement some of the key issues of waste minimisation;

- Lack of knowledge and training in the part of project team - Evidently, there is serious lack of knowledge of the environmental issues in general in the supply chain as identified in the 
literature. Consequently there is no formal training mechanism in organization or learning from other industries on how to reduce carbon emission in the supply chain;

- High capital cost of reducing or eliminating waste - because the industry already operates on very low profit margin, it will be difficult to convince the various supply chain members to buy into the idea;

- Poor Suppliers' commitment - Several authors identified poor supplier commitment as a hindrance for waste minimisation practices. They all cited lack of information, confidentiality concerns and fear of poor performance exposure for lack of commitment in addressing waste in construction;

- Nature of the clients or customers - construction industry client desire for lowest price hinder waste management practices. As documented in many research works on green supply chain, it is argued that selection of tender by clients based on lowest price will impact on any environment strategy requirement; and

- Supply chain specify challenges - it has been established that different organisations in the supply chain have different drivers, barriers and practices and these can influence how reactive or proactive organisations can respond to waste management strategies.

It should be noted that optimizing of all the listed challenges should not always be the key, tradeoffs and compromises may be necessary. Indeed, some of the issues cannot be considered immediate priorities, but this does not mean that they should be ignored. The choice of which issues to apply to a particular strategy, and the decision on the extent to which each chosen principles should be applied, reflects value judgments. Thus, the emphasis should be on implementing a waste minimisation strategy which seeks to achieve consensus among interested parties on the issues which are more relevant (Hill and Bowen, 1997). The UK construction industry aims to contribute to waste reduction or elimination by adopting new policies and practices, which have a more positive impact on economic, social and environment systems. Improvements are sought in all stages of the construction process, such as the land use, replenish of natural resources, transport networks, construction processes, embodied energy of building whilst in use, social interaction and economic benefits for the whole supply chain.

Having reviewed and grouped the literature into the legislative and supply chain issues, the study will present case study examples to illustrate these issues and how the construction industry is dealing with them. The next section describes the case study examples.

\subsection{Current Practice}

Two case studies are presented here to demonstrate the usage of waste regulations in construction. The first case study shows the full implementation of Site Waste Management Plan and the second one shows the benefits of financial incentives for effective waste management.

\subsection{Case Study 1: St Barts and the Royal London Hospital}

St Bartholomew's (Barts) and the Royal London Hospital is the biggest PFI hospital scheme and one of the top ten PFI projects in the UK. It combined two large and old hospitals to become one massive redevelopment project including transforming one old hospital into a Cancer and Cardiac Centre of Excellence. This project is worth $£ 1.1$ billion. The project consortium includes one main contractor: Skanska and two investors: Innisfree and the Dutch Infrastructure Fund. The Special Purpose Vehicle (SPV) company, Capital Hospitals, is responsible for designing, building, 
redevelopment and maintaining the hospital buildings until 2048 (Skanska, 2010). The redevelopment work began in May 2006 and scheduled to complete in 2016.

Because this project is located at the city of London, the construction sites have very limited space. How to reduce waste on site becomes the one of key objectives during the construction period. With strong commitment of local authority (City of London) and the Client, Barts and London Hospital NHS Trust and Skanska Construction Ltd, the main contractor jointly established a 'Site Waste Management Plan (SWMP)' at the early stage of the PFI procurement process. Based on the SWMP, they launched an innovation campaign to encourage reuse, reduced packaging and waste minimization on site through both the demolition and the construction stage. During this campaign, a range of innovations has been adopted to pursue their target of waste management. There are three innovations identified; firstly they used 3D model to monitor all the quantity of materials being used on site. Secondly, they used 'Just in Time' concept to establish a consolidation centre to distribute construction materials; and third they engaging with suppliers/traders to adopt the Returnable Transit Packaging (RTP) (Reusable packaging) with suppliers rather than use of traditional cupboard or plastics to reduce the end up packaging waste.

The demolition of the Victorian buildings was carried out by soft stripping, using the traditional removal of all hazardous materials and non-recyclables first, followed by salvage of materials, and structural demolition using the top-down methodology of the building from the top in a floor by floor sequence using small machines with demolition attachments such as breakers and hammers. Soft stripping allowed the materials to be segregated and sold for recycling and played a key role in achieving high recycling rates and maintaining quality source segregation. Furthermore, soft stripping exposed the structural inert materials and facilitated the recycling of concrete, steel reinforcement and brick. Crushing and sorting were primarily carried out off site at a Materials Recovery Facility (MRF). An actual recycling rate of $97.1 \%$ for the works surpassed both the Client's original $60 \%$ target and the extended $85 \%$ demolition recycling target. The attainment of this high recycling rate was driven by the Client's Environmental Policy, good working relationships, partnership and trust, early contractor involvement to develop common goals between project partners, contractual agreements, agreed sustainability objectives and technical experience (WRAP, 2006).

\subsection{Case Study 2: Newport Southern Distributor Road (SDR)}

Newport is the third largest city in Wales, a traditional small city on the bank of the River Usk. Following the UK central government's sustainable development strategy, the Newport City Council created its own 21 agenda action plan and devised a new sustainable urban regeneration strategy for the area for next decade (NCBC, 2000). However, the existing transport network is not fulfilling the demand especially on the south side of the city.

In order to relieve the transport congestion and improve the local transport network, the Newport County Borough Council (NCBC) decided to adopt the PFI model to develop a new road on the south side of the city. The proposed plan is to build a dual carriageway link from Junction 24 of the M4 (Coldra roundabout) to the east Junction 28 (Tredegar roundabout) on the Southern edge of Newport and it includes a major crossing of the River Usk. Morgan Est, one of the largest civil engineering contractors in the UK, together with Vinci, an international contracting company, formed a joint venture 'Morgan Vince Ltd' which won the $£ 55$ million contract. This comprises the Design, Build, Finance and Operation (DBFO) of the project over a 40 -year life span. This project is the biggest local authority PFI project in Wales and also recognised as a pathfinder project by the Welsh Assembly Government (NCBC, 2002).

Construction started during the summer of 2002 and the road was made fully open to traffic in December 2004 and the Southern Distributor Road (SDR) was finished half year ahead of schedule 
(May 2005). In brief, approximately $£ 1$ million initial cost was saved through the use of around 450,000 tonnes of recycled and secondary aggregates instead of purchasing primary materials. A variety of secondary aggregates was used as granular fill materials and unbound sub-base (NCBC, 2002). These included spent railway ballast, pulverised fuel ash, crushed demolition waste cleared from site, steel furnace slag and blast furnace slag (WRAP, 2004). In this project, specific cost saving methods includes:

- The avoidance of waste disposal charges and Landfill Tax;

- The avoidance of Aggregates Levy payments, by using recycled and secondary aggregates;

- The Operator of the PFI project: Ringway, used an advanced recycle technique: Foambase to make cold mixed and cold-laid materials (94\% recycled aggregates) as an alternative to hot mix base and binder course materials;

- Reduced costs of transporting aggregates when recovered materials are available locally

The Action Sustainability (2006) has examined both the capital cost saving and the whole life cost saving in detail. They outline:

"the use of recycled material did not incur additional capital or maintenance expenditure for the project; however, it did result in direct cost savings in construction costs (£1,034,135), carbon emissions (£106,481), avoiding landfill costs $(£ 941,360)$ and health benefits from reduced emissions of PM10 (particles measuring 10mm or less).Overall, £2,098,801 was saved, offset by no costs, which amounted to $3.82 \%$ of savings of the total project cost or to $£ 219,609$ per kilometer of road constructed."

\subsection{Discussion and Conclusions}

This introductory chapter has reviewed material waste in construction from the perspectives of legislation and supply chain issues. Sustainable construction has been identified as a way for the construction industry to contribute to the global sustainability agenda. This chapter outlines how various waste minimisation and reduction strategies can help to achieve environmental sustainability and consequently reduce carbon emissions. Furthermore, it is also evident from the review and the case studies reported that there are wider economic and social benefits when construction waste is accurately planned and properly managed.

According to the review, the steady depletion of the natural and non-renewable resources used in construction activities makes the subject of sustainability inevitable in the construction industry. This is because the industry consumes enormous amount of these resources and produces vast amount of waste. Perhaps, more alarming is the greenhouse gases emitted, mainly carbon, as a result of the extraction, production, transportation, assembly and disposal of these materials (i.e. from cradle-to-grave). The carbon emitted at the different life cycle phases of the building, otherwise referred to as the system boundaries is degrading our beloved built and natural environment.

In response to the above, lexicons such as green buildings and green procurement have become common currencies in construction to describe the different attempts to co-opt the issue. In addition, a number of stakeholders in the industry increasingly are (and/or want to be seen as) adopting suitable innovative practices during design and construction phase of projects to show their commitment to decarbonising the built environment. One of the strategies being adopted is green supply chain management which if well implemented can help to reduce waste a great deal in construction. Government on their part, and as a pathfinder, has come up with different legislations and policies to combat the issue of material waste in construction. 
The review in this chapter has shown that the construction industry in the UK and globally is a major producer of waste, if not the greatest contributor when compared to waste from other sectors. To put this into context, demolition and construction waste accounts for the highest composition of waste production in England according to findings. This is not to mention the construction-related waste embedded in various other sectors. Review has also shown that similar trend exists, generally in the UK, and globally. Indeed, it is clear why the construction industry, with the help of the government, must respond accordingly and swiftly.

To this end, there are a wide range of legislations and policies in the UK which have direct and/or indirect impacts on construction waste management and the need to recover resources from demolition. These are broadly classified into environmental protection and sustainable construction regulations; waste management regulations, and; fiscal policies. Whilst some of the legislations and policies are voluntary standards such as Code for Sustainable Homes (CSH) for private housing, others are simply best practice and many more a strategy document such as Waste and Resources Action Programme (WRAP), Sustainable Construction Strategy and ICE Protocol etc. However, a number of these waste management legislations are mandatory, some of which were originally employed under a voluntary code of practice such as the Site Waste Management Plan (SWMP).

Other mandatory regulations include the Hazardous Waste (England and Wales) Regulations, Environmental Protection Act (EPA) and Environmental Protection (Duty of Care) Regulations etc. Fiscal policies such as financial incentives, tax and levy are also increasingly being put in place by the government to provide a carrot and stick approach, particularly to construction waste management. Such include, for example, the Landfill Tax, Climate Change Levy and Aggregate Levy, which are all designed to promote innovative re-use and/or recycling, with landfill as a last resort, of construction/demolition materials whilst encouraging less waste production in the first place (i.e. by designing out waste) and the use of environmental friendly construction methods and materials.

The construction sector and consequently the environment will immensely benefit from the above and various other existing regulations, strategies, policies and best practice if properly implemented. The argument about the suitability of these regulations and policies to achieve waste minimisation and reduction is beyond the scope of this chapter and further research is required in this area. However, what is clear from the review in this chapter is that there are several supply chain issues which serve as barriers to waste minimisation. These are often broadly classified under one of two supply chain issues which include internal and external supply chain issues. In particular the challenges to change in the construction sector include high capital cost of reducing/eliminating waste, lack of integration in the industry, resistance to change and mind-set of the industry, and lack of knowledge and training of project team etc.

Whist the current UK legislations and policies appear to have covered the basic and/or fundamental requirements in construction waste management, it is evident that implementation is still lacking. The regulations at present are considered as a soft touch, for example, design team are sometimes able to attain excellence by paying lip service to sustainable design. Having said that, this is not to suggest more red tape as the way forward, probably not? Instead, further simplification and condensation of the current regulations and their proper enforcement is critical to implementing some of the key issues of waste minimisation in construction.

In conclusion, the best practice case studies presented in the latter part of this chapter illustrate that a holistic approach is required for construction waste management. In other words, waste minimisation and reduction strategies require a concerted effort by all involved including the government, clients, contractors, suppliers and indeed the whole supply chain. To achieve sustainability, regulating material waste in construction is fundamental and this requires 
accountability, adequate attention and effective management at every stage of a building and building materials life cycle i.e. from cradle-to-grave.

\subsection{References}

Action Sustainability (2006) Case Study Newport PFI, [Data sourced on 10/02/2007] http://www.actionsustainability.com/resources/view_casestudy.asp?CaseStudyID=13

Anderson, J., Shiers, D., \& Steele, K. (2009). The green guide to specification: an environmental profiling system for building materials and components (4th ed.). Chichester: WileyBlackwell

Barkemeyer, R., Figge, F., Holt, D., \& Hahn, T. (2009). What the Papers Say: Trends in Sustainability: A Comparative Analysis of 115 Leading National Newspapers Worldwide. Journal of Corporate Citizenship(33), 69-86.

Barrett, P. S; Sexton, M. G. and Green, L. (1999), Integrated Delivery Systems for Sustainable Construction, Building Research and Information, Vol.27, No.6, pp 398-405.

Beamon, B. M. (1999). Designing the green supply chain. Logistics information management, 12(4), 332-342.

Begum, R. A., Siwar, C., Pereira, J. J., \& Jaafar, A. H. (2006). A benefit-cost analysis on the economic feasibility of construction waste minimisation: the case of Malaysia. Resources, Conservation and Recycling, 48(1), 86-98.

BERR. (2008). Strategy for sustainable construction. London: Department for Business, Enterprise and Regulatory Reform, HM Government.

BIS. (2010). Low carbon construction: innovation and growth team. London: HM Government, Department for Business, Innovation and Skills (BIS) Retrieved from http://www.bis.gov.uk/assets/biscore/business-sectors/docs/1/10-1266-low-carbonconstruction-igt-final-report.pdf.

Bossink, B.A.G. Brouwers, H.J.H. (1996). 'Construction waste: quantification and source evaluation'. Construction Engineering and Management. 122 (1), pp 55-60.

Chaharbaghi, K. \& Willis, R. (1999), Study and Practice of Sustainable Development. Engineering Management Journal, Vol. 9, No. 1, Feb 1999.

Chen, Z., Li, H., \& Wong, C. T. (2002). An application of bar-code system for reducing construction wastes. Automation in Construction, 11(5), 521-533.

CLG (2006) Code for Sustainable Homes: A step-change in sustainable home building practice, Communities and Local Government

Crittenden, B. and Kolaczkowski, S. (1995) Waste Minimisation, A Practical Guide. Institution of Chemical Engineers, London.

CRW (2008), Construction Resources and Waste Roadmap, Construction resources and waste platform, www.crwplatform.org.uk, BRE, Garston, UK.

CRWP (2007) Developing a strategic approach to construction waste: Task 5 - Evidence Gap Analysis, Review of Legislation and Strategy.

Dainty, A.R.J., Brooke, R.J. (2004). 'Towards improved construction waste minimisation: improved supply chain integration'. Structural Survey. 22 (1), pp 20-29.

Dalhousie University's Office of Sustainability

DCLG (2006), Building a greener future: Towards Zero Carbon Development, http://www.communities.gov.uk/archived/publications/planningandbuilding/buildinggreener Accessed: $3^{\text {rd }}$ May 2008.

DECC, DEFRA, \& DfT. (2008). Climate Change Act 2008 : Chapter 27. (9780105427087). London: The Stationery Office (TSO) Retrieved from http://www.opsi.gov.uk/acts/acts2008/ukpga_20080027_en_1. 
DEFRA (2006) Procuring the Future: Sustainable Procurement National Action Plan, London, Department for Environment, Food and Rural Affairs

DETR (2000), Department of the Environment, Transport and the Regions / Construction Confederation. Guide to Waste Reduction on Construction sites. London: The Stationery Office.

Ding, G. K. C. (2005). Developing a multicriteria approach for the measurement of sustainable performance. Building Research \& Information, 33(1), 3-16.

Edum-Fotwe, F. T., \& Price, A. D. F. (2009). A social ontology for appraising sustainability of construction projects and developments. International Journal of Project Management, 27(4), 313-322.

Egan, J. (1998) Rethinking Construction: The Report of the Construction Task Force. Department of the Environment, Transport and the Regions, London, UK.

Ekanayake, L. L., \& Ofori, G. (2004). Building waste assessment score: design-based tool. Building and Environment, 39(7), 851-861.

Ekundayo, D., Perera, S., Udeaja, C., \& Zhou, L. (2011). Achieving economic and environmental sustainability through optimum balance of costs. Paper presented at the 10th International Postgraduate Research Conference in the Built Environment, University of Salford, UK.

Ekundayo, D., Perera, S., Udeaja, C., \& Zhou, L. (2012). Carbon review and qualitative comparison of selected carbon counting tools Paper presented at the RICS COBRA Research Conference, Las Vegas, Nevada USA.

Emmanuel, M. R., \& Baker, K. (2012). Carbon management in the built environment. London: Routledge.

Faniran, O.O. Caban, G. (1998). 'Minimizing waste on construction project sites'. Engineering Construction and Architectural Management. 5 (2), 182-188.

Ferguson, J., Kermode, N., Nash, C.L., Sketch, W.A.J., Huxford, R.P. (1995) Managing \& Minimizing Construction Waste: A Practical Guide. Institute of Civil Engineers. London: Thomas Telford Publications

Formoso, C. T., Soibelman, L., De Cesare, C., \& Isatto, E. L. (2002). Material waste in building industry: main causes and prevention. Journal of Construction Engineering and Management, 128(4), 316-325.

Formosso, C. T., Isatto, E. L. and Hirota, E. H. (1999) Method for Waste Control in the Building Industry. In Proceedings IGLC, Vol. 7, University of California, Berkeley, CA, USA.

Franklin and Andrews. (2010). Hutchins' small and major works: UK building costs blackbook: capital cost and embodied CO2 guide (2010 ed. Vol. Two). London Franklin \& Andrews

GCCP. (2000). Achieving sustainability in construction procurement. London: Sustainability Action Group.

Glavic, P., \& Lukman, R. (2007). Review of sustainability terms and their definitions. Journal of Cleaner Production, 15(18), 1875-1885.

Gupta, R. \& Chandiwala, S. (2007) How to commission sustainable construction in further education colleges

Hammond, G. P., \& Jones, C. I. (2008a). Embodied energy and carbon in construction materials Proceedings of the Institution of Civil Engineers - Energy, 161(2), 87-98.

Hammond, G. P., \& Jones, C. I. (2008b). Inventory of carbon and energy (ICE) Version 1.6a. UK: University of Bath.

Hicks, C., Heidrich, O., McGovern, T., \& Donnelly, T. (2004). A functional model of supply chains and waste. International Journal of Production Economics, 89(2), 165-174.

Hill, R. C. and Bowen, P. A. (1997), Sustainable Construction: Principles and a Framework for attainment, Construction Management and Economics, Vol. 15, pp 223-239.

Horvarth, A. (2004), Construction Material and the environment, Annual Review of Environment and Resources, Vol. 29, pp 181-204.

ICE (2008) Demolition Protocol, the Institution of Civil Engineers. 
Jaillon, L., Poon, C. S., \& Chiang, Y. H. (2009). Quantifying the waste reduction potential of using prefabrication in building construction in Hong Kong. Waste Management, 29(1), 309-320.

Jeffrey, C., (2011) Construction and Demolition Waste Recycling: A literature review

Khalfan, M. M. A. (2006). Managing sustainability within construction projects. Journal of Environmental Assessment Policy \& Management, 8(1), 41-60.

Khalfan, M.M.A. (2002) Sustainable Development and Sustainable Construction: A literature review for $C$-SanD. Loughborough University.

Kibert, C. J. (2007), The next generation of sustainable construction, Building Research and Information, Routledge Taylor \& Francis Group, Vol. 35, No. 6, pp 595-601.

Kwan, J., Mallett, H., Mason, S., Spencer, D. (2001) Tools for measuring and forecasting waste generated on site: Project Report 83. Department of the Environment, Transport, and the Regions. London: CIRIA.

Majdalani, Z., Ajam, M., \& Mezher, T. (2006). Sustainability in the construction industry: a Lebanese case study. Construction Innovation: Information, Process, Management, 6(1), 33-46.

Mcdonald, B., \& Smithers, M. (1998). Implementing a waste management plan during the construction phase of a project: a case study. Construction Management \& Economics, 16(1), 71-78.

McGrath, C. (2001). Waste minimisation in practice. Resources, conservation and recycling, 32(3), 227-238.

Mills, J. (2010). The civics of sustainability: An overview. National Civic Review, 99(3), 3-6.

Monahan, J., \& Powell, J. C. (2011). A comparison of the energy and carbon implications of new systems of energy provision in new build housing in the UK. Energy Policy, 39(1), 290-298.

Myers, D. (2008). Construction economics : a new approach (2nd ed.). London ; New York: Taylor \& Francis.

NCE (2007), Waste Not, Want not. New Civil Engineer magazine (04.10.07), No.1684, pp 24 - 25.

Newport City Borough Council (NCBC), (2002) Newport Southern Distributor Road PFI Schemes Full Business Case.

Newport City Council (NCC), (2004a) Southern Distributor Road Setting Standards, Newport Matters, The officer newspaper of Newport City Council, Winter Edition, p7.

Newport City Council (NCC), (2004b) SDR Bridge Open to Traffic, Press Release [data sourced on 08/02/07 www.newport.gov.uk].

Newport Council Borough Council (NCBC), (2000) Towards a Sustainable Newport, Newport.

Newport Unlimited (2007) Unlimited Vision Newport 2020: a master plan for central Newport, Newport.

Nitivattananon, V., \& Borongan, G. (2007), Construction and demolition waste management: current practices in Asia, In Proceedings of the International Conference on Sustainable Solid Waste Management, September, Chennai, India, pp. 97-104.

Ofori, G. (2000), Greening the construction Supply Chain in Singapore, European Journal of Purchasing and Supply Management, Vol. 6, pp 195-206.

Osmani, M. (2012). Construction Waste Minimization in the UK: Current Pressures for Change and Approaches. Procedia-Social and Behavioral Sciences, 40, 37-40.

Osmani, M., Glass, J., \& Price, A. D. (2008). Architects' perspectives on construction waste reduction by design. Waste Management, 28(7), 1147-1158.

Pellegrini-Masini, G., Bowles, G., Peacock, A. D., Ahadzi, M., \& Banfill, P. F. G. (2010). Whole life costing of domestic energy demand reduction technologies: householder perspectives. Construction Management \& Economics, 28(3), 217-229. doi: 10.1080/01446190903480027.

Peng, C. L., Scorpio, D. E., \& Kibert, C. J. (1997). Strategies for successful construction and demolition waste recycling operations. Construction Management \& Economics, 15(1), 4958. 
Raynsford, N. (1999). The UK's approach to sustainable development in construction. Building Research \& Information, 27(6), 419-423.

RICS. (2012). Methodology to calculate embodied carbon of materials RICS information paper (1st ed., pp. 1-25). London: RICS.

Salisbury, D. (2006). Sustainable construction: whole life cost benefits Research for Kent County Council/Interreg IIIA (pp. 1-19). London: Cyril Sweett Limited.

Shayo, H., Udeaja, C. E and Tah, J. M. H (2002), Towards a sustainable construction procurement: timber supply chain approach in Tanzania. The $1^{\text {st }}$ International Conference of CIB W107 on Creating a Sustainable Construction Industry in Developing Countries, $11^{\text {th }}-13^{\text {th }}$ November 2002, Spier, South Africa.

Shen, L. Y., Tam, V. W., Tam, C. M., \& Drew, D. (2004). Mapping approach for examining waste management on construction sites. Journal of construction engineering and management, 130(4), 472-481.

Skanska (2010) Barts and the London Hospital, UK, Aspects of Sustainability, Case Study 65.

Spence, R., \& Mulligan, H. (1995). Sustainable development and the construction industry. Habitat International, 19(3), 279-292.

Spivey, D. A. (1974) Construction Solid Waste. Journal of the Construction Division, ASCE, 100.

Srivastava, S. K. (2007), Green Supply-chain Management: a state-of-the-art literature review, International Journal of Management Reviews, Vol.9, No.1, pp 53-80.

Sturgis, S., \& Roberts, G. (2010). Carbon profiling as a solution to whole life carbon emission measurement in buildings London: Royal Institution of Chartered Surveyors.

Tam, V. W., Tam, C. M., Zeng, S. X., \& Ng, W. C. (2007). Towards adoption of prefabrication in construction. Building and Environment, 42(10), 3642-3654.

Teo, M. M. M. and Loosemore, M. (2001) A Theory of Waste Behaviour in the Construction Industry. Construction Management and Economics, Vol. 19.

UK government (2008) The Site Waste Management Plans Regulations 2008,

UK Government (2012) Environmental Protection Act 1990 (chapter. 43), Document accessed on 15 Dec 2012.

UK Government (2012) Environmental Protection Act 1990 (section 34): waste management, the duty of care, a code of practice, [Document assessed on 15 Dec 2012].

UK government (2013) Clean Neighbourhoods and Environment Act 2005 http://www.legislation.gov.uk/ukpga/2005/16/pdfs/ukpga_20050016_en.pdf [accessed on 10/01/2013].

Velazquez, L. E., Esquer, J., Munguía, N. E., \& Moure-Eraso, R. (2011). Sustainable learning organizations. The Learning Organization: An International Journal, 18(1), 36-44.

Walker, H., Di Sisto, L., \& McBain, D. (2008). Drivers and barriers to environmental supply chain management practices: Lessons from the public and private sectors. Journal of Purchasing and Supply Management, 14(1), 69-85.

WCED, \& Brundtland, G. H. (1987). Our common future: World Commission on Environment and Development. Oxford: Oxford University Press.

WRAP (2004) The Big Picture, Specifying recycled in local authority contracts for highways maintenance: good practice, Banbury

WRAP (2007) Recycling Demolition Arisings at Barts and the London Hospital, WAS006-002: Demolition Exemplar Case Study.

WRAP (2011) Waste: An Action Plan for halving construction, demolition and execution waste to landfill, WRAP and Strategic Forum, Report 010.

Yahya, K., \& Boussabaine, A. H. (2006). Eco-costing of construction waste. Management of Environmental Quality: An International Journal, 17(1), 6-19.

Yuan, H., \& Shen, L. (2011). Trend of the research on construction and demolition waste management. Waste management, 31(4), 670-679.

Zhou, L. (2009) Achieving Sustainable Development through the Private Finance Initiative Procurement Process in the UK, PhD thesis, Oxford Brookes University. 
